\title{
The Literary Heritage of Jesuits of the Polish-Lithuanian Commonwealth
}

\author{
Barbara Milewska-Waźbińska \\ University of Warsaw \\ wazbinska@uw.edu.pl
}

\begin{abstract}
Since 1565 , the Society of Jesus promoted education in the humanities. The vast majority of the Polish nobility received their education in Jesuit colleges. Jesuit preachers, writers, poets, authors of heraldic and emblem works - derived mostly from the nobilitywere understandably deeply involved in politics. The legacy of the most outstanding Jesuit authors testifies to their active participation in public life. In keeping with the specifics of the Polish case, their literary production emphasizes not only the vita activa, but also animus civilis. Political and historical themes, as well as religious motifs, played a significant role in Jesuit works. The Society's activities in the Polish-Lithuanian Commonwealth produced important works in various genres of literature, a significant portion of which was in Latin. Their poetry and prose is characterized by involvement in socio-political issues: the stormy political events and wars of the seventeenth century had a considerable effect on the compositions of the leading Jesuit authors.
\end{abstract}

\section{Keywords}

Society of Jesus - Polish nobility - Latinitas - occasional literature

Jesuits were actively engaged in the political and social life of the PolishLithuanian Commonwealth, which came into existence in 1569 after the Union of the Kingdom of Poland and the Grand Duchy of Lithuania, through the two centuries of their presence there. Their literary legacy leaves little doubt as to their substantial contribution to the cultural heritage of the country. ${ }^{1}$ In

1 The most recent synthesis of the legacy of Polish Jesuits is offered in the volume edited by Irena Stasiewicz-Jasiukowa, Wkład jezuitów do nauki i kultury w Rzeczpospolitej Obojga Narodów

(C) MILEWSKA-WAŹBIŃSKA, 2018 | DOI:10.1163/22141332-00503005

This is an open access article distributed under the terms of the prevailing CC-BY-NC license at the time of publication. 
evaluating their impressive contribution to Polish literature, it is worth mentioning that even though vast majority of the writers and poets of the PolishLithuanian Commonwealth were clergymen, the writers associated with the Society of Jesus formed the cultural and intellectual elite. Owing to the firstrate communication and information flow furnished by the Society, Polish and Lithuanian Jesuits were able to draw on the latest European literary fashions and employ innovative means of expression. In so doing, and in keeping with the spirit of the age, they concentrated on the visual and sonic qualities of poetic and oratorical discourse, as made particularly manifest in their sermons, emblematic compositions, and dramas.

The Jesuits of the Commonwealth were noted as men of learning, teachers, and spiritual leaders of young noblemen. The education they offered in their colleges all over the country in the seventeenth and eighteenth centuries concentrated on the great tradition of schools of humanities, which prioritized social education. ${ }^{2}$ Students in Jesuit colleges received a Christian education that was, however, offered in an extraordinary way. They were encouraged to produce their own creative literary, oratorical, and poetic output. ${ }^{3}$ All the Society's teachers composed their own sermons, and many of them wrote poetrychiefly in Latin. Works in Latin were prized over their Polish counterparts as, if published, they were likely to reach a wider audience throughout Europe. The Bibliotheca scriptorum Societatis Jesu established in the seventeenth century contains numerous references to the works of Polish Jesuits. Furthermore, it was easier to express the dialogue between the state and the church in Latin. Jesuit sermons, inspired by Cicero's orations, were supposed to make a greater impression on the audience; Latin verses modelled on Horace's odes undoubtedly had a peculiar sonic subtlety to them. The imitations of ancient Roman writers and poets increased the popularity of Latin. Hence, it can be assumed that Jesuit literary production contributed immensely to reinforcing the role of Latin in the Commonwealth.

i pod zaborami (Cracow-Warsaw: Wydawnictwo WAM, 2004). State of research on the influence of Jesuits on education and culture is presented in this volume by Ludwik Grzebien, vide Ludwik Grzebień, "Dotychczasowa literatura o wkładzie jezuitów polskich do nauki i kultury," in Wkład jezuitów do nauki, 31-68. See Marceli Kosman, "Jezuitów polskich obraz własny: Badania ostatniego stulecia," Odrodzenie i Reformacja w Polsce 43 (1999): 213-27.

2 See Justyna Dąbkowska-Kujko, "Jezuicka paideia," in Humanitas $i$ christianitas w kulturze polskiej, ed. Mirosława Hanusiewicz-Lavallee (Warsaw: Neriton, 2009), 153-90.

3 A similar educational system was compulsory in other European schools of secondary education. See Jakub Niedźwiedź, "Jesuit Education in the Polish-Lithuanian Commonwealth $\left(15^{6} 5^{-1773)}\right)^{\prime}$ in this issue. 
We must not forget that Jesuit circles produced prominent academic works in the arts and sciences, broadly defined. One of the most notable examples of the latter was Grzegorz Knapski's (Cnapius) (1564-1638) dictionary, Thesaurus Polono-Latino-Graecus, published in Cracow between 1621 and 1632. In the third volume of this dictionary, the author catalogued Polish proverbs (Adagia Polonica). The Jesuit Michał Jurkowski's (1682-1758) Historyje świeże i niezwyczajne (Unusual and new stories), replete with anecdotes and exempla, served as a sort of sequel to this compilation of proverbs. Konstantinas Sirvydas (c.1579-1631), a Jesuit working in Lithuania, published the Latin-Polish-Lithuanian dictionary Dictionarium trium linguarum in usum studiosae iuventutis (Dictionary of three languages intended for young educated men), and in 1683 Georg Elger published his Dictionarium Polono-Latino-Lothavicum in Vilnius (Wilno). Also worthy of note are the outstanding theological and philosophical works that enrich the Jesuit literary legacy of the Commonwealth. ${ }^{4}$

It should be remembered that the curriculum of Jesuit colleges followed the requirements of the Ratio studiorum. The subject matter taught in the seminars reflected the demands of the age. The population of the Polish-Lithuanian Commonwealth, both teachers and students, witnessed such momentous political events as the meetings of nobility at the Diet (the lower house of the parliament) and sejmik (local assemblies of landed nobility), royal elections, skirmishes, and rebellions. The wars waged by Poland in the seventeenth century against Moscow, Sweden, and the Ottoman Empire, as well as the armed rebellions by the nobility against the king (called rokosz) activated political commitments amongst the Jesuits against Protestant members of the nobility.

I do not refer here to the mere awareness of political doctrines and ideologies, ${ }^{5}$ but an authentic civic engagement. Henceforth, in the seventeenth century, the combination of religious and nationalistic elements became part and parcel of the literary legacy of Jesuit men of letters in Poland, ${ }^{6}$ who were now preoccupied with political issues, both in poetry and prose. Even the sermons delivered by members of the Society of Jesus, aside from their customary religious content, indicated preachers' civic engagement. That said, one

4 See Roman Darowski, "Zarys filozofii jezuitów w Polsce od XVI do XIX wieku," in Wkład jezuitów do nauki, 119-52.

5 Harro Höpfl dedicated a separate book on the political doctrines Jesuits were interested in. See Harro Höpfl, Jesuit Political Thought: The Society of Jesus and the State, c.1540-1630 (Cambridge: Cambridge University Press, 2004). See also Stanisław Obirek, Wizja państwa w nauczaniu jezuitów polskich w latach 1564-1668 (Cracow: Wydział Filozoficzny Towarzystwa Jezusowego, 1995).

6 See Agnieszka Czechowicz, "Katolicyzm sarmacki," in Humanitas $i$ christianitas $w$ kulturze polskiej, 191-222. 
cannot but concur with the thesis of the historian of the Society of Jesus in Poland Stanisław Załęski, who maintained that as a result of the wars waged by the Kingdom of Poland in the first half of the seventeenth century, the Jesuit writers were more interested in political matters than in any other topic. ${ }^{7}$ The fact that the legacy of the Polish Jesuits does not include didactic poetry-so prominent in the tradition of their Italian and French counterparts-is particularly striking. ${ }^{8}$ Admittedly, if an author was talented, his works assumed universal qualities even when inspired by specific political events. Such was the case of the outstanding poet Maciej Kazimierz Sarbiewski (1595-1640), well known for his excellent works.

The involvement of Polish Jesuits in domestic and foreign political affairs was evident because members of the Society-preachers, writers, poets, authors of heraldic and emblematic works - were born into the nobility: a social class that felt responsible for the common welfare of the Republic. In accordance with the contemporary political system in the Polish-Lithuanian Commonwealth, the so-called democracy of the gentry, the citizens - that is, the noblemen-influenced social and political life. They used as means of rhetorical persuasion not only their knowledge of literature and history, but also their noble birth. Characteristically, Polish Jesuits prioritized both the defense of the Catholic Church against the Protestant Reformation, along with promoting the Catholic faith in the Kingdom of Poland and in the Grand Duchy of Lithuania, and duty to their social class, in equal measure.

In the initial phase of their activity in the Commonwealth, Jesuits dedicated themselves to developing the skills of rhetorical persuasion in society, instructing future generations as well as addressing religious polemical discourses to dissenters. This was the period in which Jesuits translated the Bible into Polish. Jakub Wujek (1541-97) was the author of the translation. His version (called now Jakub Wujek's Bible) was used by the Catholic faithful for centuries and it is widely recognized as a national treasure of the Polish language and literature-considered amongst the key Polish cultural texts.

The early phase of Jesuit activity in Poland is marked by extensive evangelizing activity. The Counter-Reformation activist Marcin Laterna (1552-98) was second only to the most prominent Jesuit orator, Piotr Skarga (1536-1612). Laterna's exquisite Ciceronian Latin oration composed on the occasion of King Stefan Batory's funeral in 1588, Oratio in exequias funeris divi Stephani Primi

7 Stanisław Załęski, Jezuici w Polsce, w skróceniu, 5 tomów w jednym, z dwiema mapami (Cracow: Drukarnia W.L. Anczyca i Spółki, 1908), 42.

8 This genre is analyzed in detail by Yasmin Haskell in her book on Jesuit Latin didactic poetry in Europe: see Yasmin Haskell, Loyola's Bees: Ideology and Industry in Jesuit Latin Didactic Poetry (Oxford: Oxford University Press, 2003). 
(Oration on the funeral of the late Stefan Batory), is a prime example of an occasional sermon. Laterna was also the author of the regularly re-printed prayer book in Polish, Harfa duchowna (The spiritual harp, 1585).

It should be observed that, since the emergence of the Society in Poland, Jesuits were regularly appointed as royal preachers, which testifies to their social and political involvement. Laterna, for instance, delivered sermons for the royal court of Batory. Amongst the other appointed royal preachers there were Skarga, the moralist Mateusz Bembus (1567-1645), poets and writers Sarbiewski and Seweryn Karwat Wojcikiewicz (1605-64), and theologian Szymon Wysocki (1542-1622). The latter was also the confessor of the Swedish Queen Catherine Jagiellon and a tutor to her son, the future King Sigismund III.

The preacher Mateusz Bembus wrote an evocatively titled work, Bellator christianus (The Christian warrior), a manual for soldiers, not an imitatio Christi addressed to the general public such as Erasmus's Enchiridion. Bembus instructed his readers how to wage war in a Christian spirit. This work, first printed in Cologne in 1617, and later in Cracow, included a dedication to Prince Władysław Vasa, the future king of Poland, who was to embark on a military expedition against Moscow. Furthermore, Jesuits would usually promote the value of ethics of military service, following Antonio Possevino's Il soldato cristiano, published in 1569 in Rome. This celebrated treatise heavily influenced Piotr Skarga's Żotnierskie nabożeństwo (Soldier's prayer) (Cracow, 16o6), and Mateusz Bembus's above-mentioned work. ${ }^{9}$

The Jesuit Stanisław Grodzicki (1541-1613), who dedicated his life to converting Lithuanian Protestants, was renowned as an orator and missionary. An activist against the Polish Brethren as well as a prolific writer and Jesuit polemicist, Mikołaj Cichowski (1598-1669) was also involved in the union with the Orthodox Church, as can be seen in his work Colloquium Kioviense de processione Spiritus Sancti a Patre et Filio inter [...] Innocentium Gizel [...] et Nicolaum Cichovium, published in 1649. Another polemicist, Adam Makowski (c.1575-1657), composed occasional sermons on mainly political subjects. This Jesuit gave a speech on the occasion of King Władysław IV's departure for the war against Moscow in 1633. Upon the monarch's happy return, Makowski greeted the king accordingly, reflecting on the events of the war. Adrian

9 Mirosław Lenart, Miles pius et iustus: Żotnierz chrześcijański katolickiej wiary w kulturze $i$ piśmiennictwie dawnej Rzeczpospolitej (XVI-XVIII w.) (Warsaw: Instytut Badań Literackich PAN, Stowarzyszenie "Pro Cultura Litteraria," 2009), 65-83. See Damien Tricoire, "To Fight, or not to Fight: Piotr Skarga S.J., the Catholic Ideal of Christian Soldier, and the Reformation of Polish Nobility (around 160o)," Journal of Jesuit Studies 4, no. 4 (2017): 624-36. See also Vincenzo Lavenia, "Jesuit Catechisms for Soldiers (Seventeenth - Nineteenth Centuries): Changes and Continuities" Journal of Jesuit Studies 4, no. 4 (2017): 599-623. 
Pikarski (1615-79), later a royal preacher to the kings Jan II Kazimierz, Michał Korybut Wiśniowiecki, and Jan III Sobieski, participated in the military venture as a chaplain in Stefan Czarnecki's division. He preached sermons in the military camps and was the author of a diary of the war against the prince of Transylvania George II Rákóczi, Diarium bellici progressus cum Georgio Rakocio. Ex castris ad Miedzybor 23 Julii 1657 (A war diary on the war against George II Rákóczi. From the camp at Międzyborz. July 23, 1657).

The seventeenth and eighteenth centuries brought numerous Latin and Polish sermons and orations by Polish Jesuits that were published as occasional prints or remained in manuscript. They now provide a valuable insight into the rhetorical proficiency of the Jesuits, as well as the history of the PolishLithuanian Commonwealth. These sources also allow us to outline the history of noble families mentioned by the orators. As expert orators, Jesuits published their model orations and textbooks with rhetorical examples. Jakub Olszewski (1585-1634), whose occasional sermons were published in Vilnius in 1645, copiously quoted biblical passages and ancient historical works. ${ }^{10}$ Aleksander Lorencowicz (1605-75), another renowned preacher, published a pattern book including funeral sermons dedicated to clergy and laymen of noble birth. In his sermons, intended to record the events of his day, he extolled laudable deeds and reproached the abuses of the nobility and the middle class. Pattern books of funeral sermons commemorating the deceased noblemen were also composed by the Jesuits Piotr Dunin (1633-1704) and Jan Legucki (1673-1752). ${ }^{11}$

Stanisław Warszewicki (c.1527-91), secretary to King Sigismund II Augustus, was one of the most gifted Jesuit literati in the early years of the Society of Jesus in the Commonwealth. He made his name in Europe as a young man by translating into Latin the ancient Greek romance by Heliodorus of Emesa. His Aethiopicae historiae libri (Ethiopian history) was first published in Basel in 1552, before Warszewicki joined the Society. Involved in missionary work, he left behind a sizeable corpus of letters that now serves as a valuable historical record of the Catholic Counter-Reformation and of Polish history in that period.

Experimentation in literary form was now increasingly coming into vogue in Jesuit circles. Wawrzyniec Susliga $(c .1580-1640)$ was a notable writer in this respect. This celebrated preacher penned a number of Latin panegyrics in which one can find literary representations of the poesis artificiosa (pattern poetry) genre. In a collection of poems published in 1598 on the consecration

10 See Bogdan Rok, "Druki żałobne w dawnej Polsce XVI-XVIII w.," in Wesela, chrzciny i pogrzeby wXVI-XVIII wieku: Kultura życia i śmierci, ed. Henryk Suchojad (Warsaw: Wydawnictwo Naukowe Semper, 2001), 187-201.

11 Rok, "Druki żałobne," 196. 
and ordination of Bishop Franciszek Łącki, ${ }^{12}$ he included visual poems shaped as a bishop's insignia. Other collections of pattern poems compiled by Jesuits were published in the seventeenth and eighteenth centuries. Scholars link this phenomenon to the concurrent expansion of school networks, ${ }^{13}$ including that of Jesuit colleges. Compulsory school assignments were intended to expand memory and attention; ${ }^{14}$ they offered instruction in the composition of pattern poetry, as well as helping to teach the classical languages, especially Latin. Additionally, pattern poetry proved a propitious literary medium for religious works and eulogies.

Wawrzyniec Bojer, born in Sweden, but it was while serving in Poland at the court of Sigismund III Vasa that he championed the cause of early seventeenth-century Jesuit poetry. Bojer was noted for Latin epic works, including the Carolomachia, published in 1606 in Vilnius, about the battle of Kircholm (1605, now Salaspils in Latvia) between the field hetman of Lithuania, Jan Karol Chodkiewicz (156o-1621), and Charles Ix of Sweden (r.1607-1611). The work was highly acclaimed by his contemporaries. ${ }^{15}$ Carolomachia contains a dedicatory prose note to the future king, Prince Władysław IV Vasa, as well as a noteworthy poem. The Jesuit poet employed the parodia sacra poetic technique, later masterfully exercised by Sarbiewski, among others. Imitating the meter and expressions of Horace's opening ode dedicated to Maecenas, ${ }^{16}$ Bojer addressed Prince Władysław as follows:

O princeps atavis edite regibus, $\mathrm{O}$ et delicium dulce tui Patris, Una et summa domus spes Iageloniae.

(Prince, thou art born from the royal ancestors, the love of thy father is sweet, one and only and greatest hope of Jagiellons.)

12 Wawrzyniec Susliga, Reverendissimo in Christo Patri [...] Francisco tacki [...] Gratulatio a Laurentio Suslyga (Cracow: In Architypographia Regia et Ecclesiastica Lazari, 1598).

13 See Piotr Rypson, Piramidy, stońca, labirynty: Poezja wizualna w Polsce od XVI do XVIII wieku (Warsaw: Neriton, 2002), 70.

14 See Seraina Plotke, Gereimte Bilder: Visuelle Poesie im 17.Jahrhundert (Munich: Fink, 2009), 203 .

15 Juliusz Nowak-Dłużewski, Okolicznościowa poezja polityczna w Polsce: Zygmunt III (Warsaw: Instytut Wydawniczy PAX, 1971), 390.

16 It is a reference to the opening of Horace's poem. See Hor. Carm. 1,1-2: "Maecenas atavis edite regibus, / o et praesidium et dulce decus meum." See Quintus Horatius Flaccus, $O p$ era, ed. Fridericus Klingner (Leipzig: Bibliotheca Scriptorum Graecorum et Romanorum Teubneriana, 1970), 1. 
References to Horace in Latin poems were a popular stylistic device amongst Jesuits. The most prominent Polish poet of the seventeenth centurySarbiewski-was unrivalled in this respect. ${ }^{17}$ Poems inspired by Horace employed elaborate lexical and structural elements characteristic of the ancient lyricist's works. Such emulation of the old masters makes evident the intersection of antiquity and Christianity. Numerous allusions to ancient gods and goddesses were not only anything but extraordinary, but indeed part and parcel of the contemporary literary trend. Would-be poets were taught the art of allegorical interpretation of myths, in keeping with Christian morality, in their early school days. Sarbiewski's Dii gentium (Pagan gods) exemplifies the didactic treatise in prose that lists a variety of methods of mythical interpretation. ${ }^{18}$ Pagan gods and goddesses such as Cupid and Venus, for example, were seen as a possible point of departure for contemplating the divine love. It is worth noting that in the eighteenth-century Polish Jesuits repudiated such allegorical interpretations of mythology. Instead, the rational and historical description of myths began to win wider support. ${ }^{19}$ Sarbiewski devoted his Latin treatise De perfecta poesi sive Vergilius et Homerus (On perfect poetry, namely Virgil and Homer) as well as four short essays Praecepta poetica (Lectures on poetics) designed for his students, to the various aspects of the nature of poetry and the theory of poetic creativity.

It is well known that Sarbiewski was hailed as the "Christian Horace." His most famous work was his collection of four books of Latin odes and a book of

17 Motiejus Kazimieras Sarbievijus lietuvos, lenkijos, europos kultūroje: Tarptautinès mokslinès konferencijos, skirtos poeto 4oo-uju gimimo metiniu jubiliejui, medžiaga, ed. Eugenija Ulčinaitè (Vilnius: Lietuvių literatūros ir tautosakos institutas, 1995); Jesuitica: Kolokwium naukowe z okazji 40o. rocznicy urodzin Macieja Kazimierza Sarbiewskiego, ed. Jan Malicki and Piotr Wilczek (Katowice: Wydawnictwo Uniwersytetu Śląskiego, 1997); Piotr Urbański, Theologia Fabulosa: Commentationes Sarbievianae (Szczecin: Wydawnictwo Naukowe Uniwersytetu Szczecińskiego, 200o); Aleksander Wojciech Mikołajczak, Studia Sarbieviana (Gniezno: Tum, 1998); Elwira Buszewicz, Sarmacki Horacy i jego liryka: Imitacja - gatunek - styl; Rzecz o poezji Macieja Kazimierza Sarbiewskiego (Cracow: Księgarnia Akademicka, 2006); Maciej Kazimierz Sarbiewski i jego epoka: Próba syntezy, ed. Jakub Zdzisław Lichański (Pułtusk: Akademia Humanistyczna im. Aleksandra Gieysztora, 2006); Sarbiewski: Der polnische Horaz, ed. Eckart Schäfer (Tübingen: G. Narr, 2006); Casimir Britannicus: English Translations, Paraphrases, and Emulations of the Poetry of Maciej Kazimierz Sarbiewski, ed. Krzysztof Fordoński and Piotr Urbański (London: Modern Humanities Research Association, 2010).

18 Krystyna Stawecka, Maciej Kazimierz Sarbiewski prozaik i poeta (Lublin: Wydawnictwo Towarzystwa Naukowego KUL, 1989), 41-72.

19 See Marek Prejs, Poezja późnego baroku: Gtówne kierunki przemian (Warsaw: Państwowe Wydawnictwo Naukowe, 1989), 138. 
epodes, designed to emulate the odes and epodes of the most famous ancient Roman lyricist. Sarbiewski's poems were first published in Cologne in 1625 as Lyricorum libri III. However, the most impressive edition, featuring a title page adorned with a copperplate engraving designed by Peter Paul Rubens (15771640), was published by Baltazar Moret as Lyricorum libri Iv: Epodon liber unus alterque epigrammatum in 1632 in Antwerp.

As a spiritual disciple of Ignatius of Loyola (c.1491-1556), Sarbiewski concentrated on proselytizing and laudatory works. Close examination of the Bible combined with an admiration for Horace resulted in a remarkable work that employed classical poetic form to convey the Christian message. Pagan as Horace's works might be, Sarbiewski used their great poetic legacy, but adapted it to a different cultural circle. He wanted to express emotions like the ancient masters, in this case his intense religious devotion.

Ode 19 from the Libri lyricorum, entitled Ex sacro Salomonis epithalamio, and prefaced by a quotation from Song of Songs, confirms this seemingly mutually exclusive attention to the artistry of Horace's odes and dedication to biblical symbolism. It features the familiar comparison of a lover to a roe deer. This poem, structurally and lexically, paraphrases Horace's erotic ode 23 (from Book I of Lyrics). Here, the lyrical "I" compares a timid but marriageable girl to a fawn. The poetic paraphrase was stimulated by the resemblance to the mentioned biblical passage: "Similis est dilectus meus capreae, hinnuloque cervorum"20 (My beloved is like a roe or a young hart) to the opening lines of Horace's ode: "Vitas inuleo me similis"21 (You avoid me like a fawn). Structured like Horace's ode, Sarbiewski's poem, written in the second asclepiad, opens with a similar passage, "Vitas sollicitae me similis caprae" (You avoid me like a skittish chamois), which is, however, intended to address Christ. As such, the passage employs the poetic device of combining the opening clause, drawing on Horace, with a clause alluding to the biblical passage at the other end of the verse. In doing so, Sarbiewski alludes to deer as a Christian symbol, which refers to Christ and human soul in search of God. ${ }^{22}$

Sarbiewski imitated both Horace's poetic style and his attitude towards society. A member of the Society of Jesus and a Polish nobleman, Sarbiewski made no secret of his socio-political sentiments, as Horace had not concealed his Roman roots. Hence, the Jesuit poet does not hesitate to remind the reader of such noble privileges as golden liberty (aurea libertas) in Ode 38 of Book IV,

\footnotetext{
$20 \quad$ Song of Songs 2.9.

21 Hor. Carm. 1.23,1, in Quintus Horatius Flaccus, Opera, 26.

22 See Józef Budzyński, Horacjanizm w liryce polsko-tacińskiej Renesansu i Baroku (Wrocław: Ossolineum, 1985), 184-86.
} 
titled Ad libertatem: Cum Vladislaus IV maximis ad Vistulam comitiis rex Poloniae renuntiaretur (On liberty: Upon the election of King Władysław IV during the proceedings of the Diet by the Vistula River). The poet addresses the new monarch as follows:

\section{Salve! Secundis te Lechici patres \\ Et Martiorum castra Quiritium \\ Regem salutavere votis; ${ }^{23}$ \\ (Be welcome! Fathers coming from Lech as well as the camp of Quirites coming from Mars welcomed you after the successfully completed election.)}

Thus Sarbiewski's artistic persona was determined both by his affiliation with the Jesuits and his political commitment to noble privileges. In short, Sarbiewski's religious references, used as a substitute for Horace's sometimes overtly erotic subject matter, went hand-in-hand with his socio-political themes.

Noted for his creative poetic artistry, Sarbiewski justifiably became the most published Polish literary export, despite — or perhaps due to - the fact that he wrote solely in Latin. It should not escape our attention that his poems voiced alarm about Europe being harried by the Ottoman Empire. Ode 6 of Book I addresses the rulers Ad principes Europae: De recuperando orientis imperio (To the rulers of Europe: On the reclamation of power in the East), and Ode 12 of the same book is titled Ad principes Romani Imperii: De recuperandis Graeciae provinciis (To the rulers of the Roman Empire: On the repossession of Greek provinces). Further, Ode 20 of Book I is addressed to the sovereigns of Italy, $\mathrm{Ad}$ principes Italiae: De recuperando Orientis imperio (To the rulers of Italy. On reclaiming power in the East), and Ode 19 of Book III, is addressed to the military, Ad militares Europae ordines: De provinciis Graeciae recuperandis (To the military forces of Europe: On the reclamation of the Greek provinces). Sarbiewski often proudly describes Polish military encounters with the Turks, including the victorious battle at Khotyn in $1621 .{ }^{24}$ Sarbiewski's works also feature references to the church charities founded by the champion of Khotyn (Chocim), the Grand Lithuanian hetman Jan Karol Chodkiewicz in May 1621, prior to his expedition. ${ }^{25}$ Emotionally involved in the war with the enemy, Sarbiewski

23 Maciej Kazimierz Sarbiewski, Lyr. IV 38, vv. 77-79, in Maciej Kazimierz Sarbiewski, Liryki oraz "Droga rzymska" i fragment "Lechiady," ed. Mirosław Korolko and Jan Okoń (Warsaw: Instytut Wydawniczy PAX, 1980), 434.

24 Sarbiewski, Lyr. I 15; II 22; IV 4, in Liryki oraz "Droga rzymska," 6o-62, 164-66, 310-14.

25 Sarbiewski, Lyr. II 11; III 27, in Liryki oraz “Droga rzymska," 128-30, 270-72. 
glorified the Polish kingdom and stressed its role as the pillar of Christianity (antemurale christianitatis):

Victor Polonus dum posita super

Respirat hasta, sic etiam vigil

Saevusque. ${ }^{26}$

(When the victorious Pole, bolstered by the spear, catches his breath, he is vigilant and dangerous.)

Students of the Jesuit colleges in Poland in the seventeenth and eighteenth centuries were taught to compose all sorts of occasional works. The instruction was not limited to prose speeches for visiting secular dignitaries or clergy, but extended to composing poems in their memory. Occasional poems also lent themselves to commemorating other significant events in order to save them from collective amnesia. Poems composed on the occasion of the marriage or death of high-profile figures or their relatives were produced in abundance. Military events also became the subject of occasional poems. For instance, nearly forty of Sarbiewski's epigrams were dedicated to Chodkiewicz. ${ }^{27}$ The high level of Sarbiewski's poetic artistry, and the popularity the poet had gained, spurred other Jesuit authors to make similar poetic attempts, using similar techniques, namely lyric occasional poetry and Horatian phrases.

Sarbiewski was an established neo-Latin poet and venerated in Poland already in his lifetime. The Jesuit Jan Rywocki (c.16oo-66), in his panegyric Monumentum gratae testificationis (The monument of gratitude) praising King Władysław IV for his high esteem for humanistic education, celebrated the conferral of a doctorate in theology (laurea theologica) on Sarbiewski. The ceremony took place in Vilnius in 1636 in the king's presence. As mentioned above, Sarbiewski's fame resonated far beyond national borders. ${ }^{28}$ Lectures in rhetoric and poetics at European colleges were supplemented by quotations from his works. ${ }^{29}$ Sarbiewski was after all reckoned among the top Latin lyrical

\footnotetext{
26 Sarbiewski, Lyr. IV 4 vv. 13-15, in Liryki oraz "Droga rzymska," 310.

27 Justyna Zaborowska-Musiał, Epigramy Macieja Kazimierza Sarbiewskiego (Pułtusk: Wyższa Szkoła Humanistyczna im. Aleksandra Gieysztora, 2006), 101.

28 See Lebrecht Gotthelf Langbein, Commentatio de Mathiae Casimiri Sarbievii S.I. Poloni vita studiis et scriptis (Dresden: Apud Fridericum Heckelium, 1754), 121-46.

29 Maciej Kazimierz Sarbiewski, Wyktady poetyki: Praecepta poetica, ed. Stanisław Skimina (Wrocław-Cracow: Ossolineum, 1958), 1. See Józef Warszawski, "Dramat rzymski” Macieja Kazimierza Sarbiewskiego TJ (1622-1625): Studium literacko-biograficzne (Rome: Pontificia Università Gregoriana, 1984), 340.
} 
poets, often compared to Horace. His poems became part of school curriculum and served as a model of perfect poetry. ${ }^{30}$

Sarbiewski in turn thought highly of fellow Jesuit Mikołaj Kmicic's $(1601-32)^{31}$ poetry. Andrzej Kanon (1612-85), the author of Lyricorum Libri IV: Epodon liber unus (Cracow, 1643) can be regarded as a literary successor of Sarbiewski. In his Latin odes, he too seeks to align Horatian poetic form with current events and contemporary topics. Kanon dedicated his poems primarily to the most venerated saints associated with the Society of Jesus-hierarchs, rulers, and magnates-hence their panegyrical tone. Ode I of Book, II dedicated to King Władysław IV, closes with a passage asserting the monarch’s longlasting renown:
Dum Roma stabit, dum Iagelonium
Astris legetur nomen et inclyti
Vivent in argento triumphi
Sculpta tuae monumenta pugnae.
Et ipsa fortes Lechia quamdiu
Reges habebit, dum memores tui
Olim renarrabunt Poloni
Magnanimo tua facta Nato. ${ }^{32}$

(As long as Rome shall stand, the good name of Jagiellons shall remain inscribed in the stars and the silver-engraved victories, the monuments of this battle. As long as Lechia itself shall be ruled by kings, your devoted Poles shall once pass the knowledge of your deeds to your generous son.)

Kanon was also an author of poems in hexameters that sought to honor his homeland, Liber poematum continens Lechica admiranda (The book of poems recounting the admirable affairs of Lechia), in which the Jesuit included poetic descriptions of the salt mine in Bochnia near Cracow, as well as of the Polish landscape in winter.

30 See a clear reference to Sarbiewski's poetry in Lyricorum libri IV et Epodon liber unus (Vienna: J. Blaeu and A. Harttung, 1670), 174-75, by the Italian Jesuit poet Nicola Avancini (1611-86).

31 Eugenija Ulčinaite, "Szkoła poetycka Sarbiewskiego na Litwie w XVII-XVIII wieku," in Corona scientiarum: Studia $z$ historii literatury i kultury nowożytnej ofiarowane Profesorowi Januszowi Pelcowi, ed. Juliusz Chrościcki et al. (Warsaw: Neriton, 2004), 373-82.

32 Andrzej Kanon, Lyricorum libri IV: Epodon liber unus et alter poematum continens (Cracow: In Officina Typographica Christophori Schedelii, 1643), 104. 
While discussing Jesuit poetry, one should not overlook the works of Albert Ines (1619-58), the author of Latin lyrical poems, epigrams, and the didactic work Lechias ducum, principum ac regum Poloniae (The Lechiad of princes, rulers, and kings of Poland). The latter seeks to catalogue Polish rulers in a poetic and narrative form. They are referred to as elogia, a literary genre widely in use throughout the seventeenth and eighteenth centuries. Originating in the rhetorical tradition, the elogium has a distinctive graphic and layout. Centeraligned, the text fits into an inscription plate. The text arrangement is linear, as opposed to metrical. The Jesuit historian Kazimierz Wieruszewski (16821744) - the author of Elogia heroica dedicated to Stanisław Kostka (1550-68) and other Jesuit saints - was a leading exponent of poetic stone engravings.

Agnieszka Borysowska's book confirms that Ines should take his place on the Jesuit Parnassus next to Sarbiewski. ${ }^{33}$ Although essentially religious, his poetry intermittently echoes the events of his time. In Ode 9 of Lyricorum centuria, Ines writes:

Binis, Poloni, collibus eminet

Parnassus: unum si dominus premit

Apollo, non Marti capacem

Sarmatico negat alter aedem.

(Poles! Two peaks of Parnassus tower high above: if Apollo refuses one, the other does not deny the Sarmatian Mars its ample dwelling. ${ }^{34}$

Ines's collected epigrams, which feature religious and satirical poems as well as stemmata - coat of arms poems - won him the moniker of the Polish Martial.

Other poets also deserve mention. The Flemish Jesuit Karol Malapert (15811630) lived in Poland and worked as astronomer. However, in 1615 he published in Kalisz Variorum poematum fasciculus (Volume of miscellaneous poems), in which he included Latin elegies and other poems, as well as the tragedy $S e$ decias. Jan Ćwiękalski (1618-90) wrote Latin lyrical odes and a panegyric dedicated to the archbishop of Lviv (Lwów), Jan Tarnowski (1585-1669). Seweryn Karwat, already mentioned above, wrote a panegyric in hexameter, Siradia trabeata (Sieradz attired in a ball gown), dedicated to Grand Crown Hetman Stanisław Koniecpolski (1591-1646). The poem was first published in Cracow in 1633 and later re-published. Karwat's works were translated into Polish by Samuel Twardowski (c.1595-1661). In 1633, Karwat's elegy Lachrymae vectigales

Agnieszka Borysowska, Jezuicki vates Marianus: Konterfekt osobowy i literacki Alberta Inesa (1619-1658) (Warsaw: Instytut Badań Literackich PAN, 2010).

Quotation after Borysowska, Jezuicki vates Marianus, 66-67. 
magnis manibus magni Sigismundi III Poloniae et Sueciae regis (Tears upon the ashes of the great king of Poland and Sweden, Sigismund III) was published upon the death of the monarch.

Religious themes permeate the collection of poems devoted to the Virgin Mary published in 1666 by the Jesuit Walenty Biatowicz (or Białowicz) (c.1640$78),{ }^{35}$ who was noted for his numerous occasional poems. ${ }^{36}$ Biatowicz's poetry is clearly inspired by the works of Sarbiewski. ${ }^{37}$ Religious poems were also composed by Michał Krasuski (1621-76): in the collection Regina Poloniae augustissima Virgo Mater Dei Maria (Blessed Virgin Mary, queen of Poland, mother of God, Kalisz 1669) he included over a hundred poems dedicated to holy images of the Mother of God found in Poland and Lithuania, intended to solace Poles during wars. The collection confirms the fact that religious poetry often blended with contemporary political matters. Sarbiewski's muse was invoked in the Latin lyrical poems of Franciszek Leśniewski (1720-98), who referred to his master, Sarbiewski, as saeculi superioris poetarum princeps (the prince of poets of the past century). ${ }^{38}$ Leśniewski imitated Sarbiewski not only in terms of poetic form, but also his political sentiments and poetic attitudea bard speaking openly to the nation and calling it to arms after the First Partition of 1772.

Józef Baka (1707-80), an eighteenth-century poet and Jesuit serving in Lithuania, was a poet of a different sort. Largely metaphysical and deeply rooted in baroque aesthetics, his poems are presently being reevaluated and newly appreciated. Although Baka authored an occasional Latin panegyric, he wrote primarily in Polish. Dominik Rudnicki (1676-1739) also wrote poems in Polish and Latin, characterized by their formal experimentation. His attention to the sonic qualities of poetry seems particularly noteworthy. ${ }^{39}$ Due to its distinguishing folk tinge, his religious poetry won wider appeal in society. Both Baka's and Rudnicki's poetry reflect the ideological climate of the late baroque. ${ }^{40}$

35 Genialis parodia de B. Virginis Mariae immaculata conceptione (Vilnius: Typis Academiae Societatis Jesu, 1666).

36 See Budzyński, Horacjanizm w liryce, 206.

37 Ulčinaitè, Szkota poetycka, 376.

38 Maria Garbaczowa, "Franciszek Leśniewski i jego łacińskie poezje," Rocznik świętokrzyski 21 (1994): 85-93.

39 Maria Eustachiewicz, Twórczość Dominika Rudnickiego 1676-1739 (Wrocław: Ossolineum, 1966).

40 Alina Nowicka-Jeżowa, "Poezja jezuicka po Sarbiewskim - Zarysy dróg twórczych," in Nauka z poezji Macieja Kazimierza Sarbiewskiego S.J., ed. Jacek Bolewski, Jakub Z. Lichański, and Piotr Urbański (Warsaw: Bobolanum 1995), 165-88. 
In the second half of the seventeenth century, many artists and intellectuals, including distinguished Jesuit scholars, were associated with the royal court of Jan III Sobieski (1629-96). With the support of the king, they could publish their Latin and Polish works. ${ }^{41}$ The architect Bartłomiej Wąsowski (1617-87) was also a man of letters: besides the extant manuscript of his travel diary to Europe, Europaea peregrinatio, during his years as a tutor to Mikołaj and Zygmunt Grudziński of Złotów, Wąsowski also wrote a play. The Jesuit Adam Przeborowski (1629-83) was a preacher, confessor, and secretary to King Jan III. However, the most illustrious among the orators was his contemporary Tomasz Młodzianowski, the author of orations and homilies as well as theological and philosophical works. His Latin lectures (Praelectiones) were published and then reprinted in Gdańsk, Lviv, Leszno, Cracow, and his collected works in Mainz in Germany. The Jesuit Piotr Kwiatkowski (1637-1747) composed ascetic works inspired by Ignatian spirituality, as well as moral poems included in the collection Theatrum zycia ludzkiego (The theatre of human life) published in Kalisz in 1744.

During the reign of Jan Sobieski III and later on in the first half of the eighteenth century, Jesuit literature became more distinctly panegyrical. Jesuits adopted laudatory discourse, dedicating occasional poems to their patrons and beneficiaries - usually magnates - on behalf of the Society, Jesuit colleges, or themselves, for that matter. Jesuit writers assumed the register and lifestyle of the nobility, shared their ideological proclivities, and defended their civil liberties. The Jesuit Walenty Pęski (1632-81)—nearly Sobieski's peer—was a follower of such ideology and a representative of the Sarmatian gentry-that is, the seventeenth- and eighteenth-century Polish nobility. He penned a coursebook on rhetoric-extant in manuscript-Palatium reginae libertatis rempublicam oratoriam continens (The palace of the queen of liberty accommodating the eloquent republic).$^{42}$

Interestingly enough, although many Jesuit colleges maintained printing houses, manuscripts still circulated relatively widely in the Commonwealth. Sarbiewski's aforementioned treatises on poetry and myths-already accessible in many manuscripts - were printed only in the twentieth century.

41 See Karolina Targosz, Jan III Sobieski mecenasem nauk i uczonych (Wrocław: Ossolineum, 1991); Bogdan Lisiak, "Kontakty naukowe Jana III Sobieskiego z Adamem Kochańskim sJ i innymi jezuitami," in Primus inter pares: Pierwszy wśród równych, czyli opowieść o królu Janie III, ed. Dominika Walawender-Musz (Warsaw: Muzeum Pałac w Wilanowie, 2013), 127-33.

42 Jerzy Lukowski, "Political Ideas among the Polish Nobility in the Eighteenth Century (to 1788)," The Slavonic and East European Review 82, no. 1 (2004): 1-26. 
Similarly, Pęski's coursebook circulated in Poland in its original Latin version and in Polish translation. Szymon Majchrowicz (1717-83), two generations after Pęski, devoted his treatise Trwatość szczęśliwa królestw albo ich smutny upadek (The happy standing of kingdoms or their sad decline, 1764) to the Sarmatian ideology.

Frequent family celebrations, such as weddings, baptisms, or funerals, which now begged for increasingly elaborate forms of expression - often literarywere inextricably linked to the Sarmatian lifestyle. Educated and nobly born, Jesuits offered themselves in the service of the latter. It so happened that religious discussions turned into political disputes. As a result, the commissioned works, essentially propagandistic, were a venue for an exchange of political ideas. They were to assert the authority of the dedicatee and the author, as well as raise public spirit.

A prolific panegyrist and rhetorical theorist, the Jesuit Jan Kwiatkiewicz (1630-1703) dedicated his major works, Suada civilis (Public speech) and Phoenix rhetorum (The phoenix of rhetoricians) to studying the art of speech. These works were later reprinted both in Poland and abroad. Kwiatkiewicz also composed a Latin panegyric in hexameter, Laurus prodroma ad coronam, seu carmen triumphale Victori Orientis (The laurel announcing crown or a triumphant song to the victor of the East), dedicated to Jan III Sobieski upon the defeat of the Turks at Khotyn in 1673. This poem, adorned with an allegorical plate, was published in 1674. A similar copperplate engraving can be found in Kwiatkiewicz's 1676 panegyric, Mars Poloniae coronatus (The crowned Mars of Poland), glorifying the Polish army and its heroes. The Jesuit Wojciech Bartochowski (1640-1708) published the panegyric Fulmen OrientisJoannes III rex Poloniarum ter maximus (The thunder of the East Jan III king of Poland thrice-greatest) (Kalisz, 1684) within a year of the victory at Vienna. Full of admiration for the Polish king, the poem emerged as a direct reaction to this momentous-both for Poland and Europe-political event. This text also features a copper engraving: an allegorical representation of Jan III Sobieski's triumph. It contains a short poem opening a solemn oration and a closing elogium.

Political involvement is also manifest in the Polish and Latin Jesuit works during the reign of the House of Wettin (1697-1763). Jan Skorski (1701-52) wrote a monumental Latin epic in twelve books, Lechus, published in Lviv in 1745, during the reign of King Augustus III (r.1733-63). This work tells the story of the beginnings of the Polish nation, much like Virgil's Aeneid relates the origins of Rome. Skorski narrates the journey of Lech, the progenitor of the Polish nation, to Greece. Lech seeks to reclaim his nation's legacy-the golden fleece (vellus aureum) — which is to symbolize "the golden kingdoms" 
(aurea regna) along with its dearest treasure, "the golden noble liberty" (aurea libertas). ${ }^{43}$

Heroica poesis (Heroic poetry, 1704), a Latin work by Łukasz Słowicki (1654-1717), serves different purposes. The first part (nine odes in hexameters) contains religious references to the mystery of birth and death of Christ, the chastity of the Virgin Mary, and the lives of the martyrs, including Polish saints: Stanisław of Szczepanów (c.1030-79) and Stanisław Kostka. These odes are followed by a panegyric in six cantos dedicated to King Augustus II (r.1697-1706 and 1709-33), Cardinal Michał Radziejowski (1645-1705), and the bishop of Cracow, Andrzej Trzebicki (1607-79).

The Jesuit Bartłomiej Luder (1677-1747) was noted for praising Roman Catholic saints in his Latin poems. He also authored a number of stemmata on the coats of arms of Polish noble houses. The teacher and rhetorical theorist Adam Malczewski (1680-1754) left behind diverse exemplary Latin orations, both in verse and prose. His books contain model elegies dedicated to the life of St. Stanisław Kostka and panegyrics to high-profile figures. Likewise, the Jesuit theologian and mathematician Wojciech Bystrzonowski (1699-1782) was also a teacher and theoretician of rhetoric. His book Polak sensat w liście, $w$ komplemencie polityk, humanista $w$ dyskursie, w mowach statysta, na przyktad dany szkolnej mtodzi (The Pole, the man of decorum in his correspondence, the man of tact in his addresses, a humanist in his discourses, a statesman in his speeches, held up as an example to our youth in their schools), dedicated to young people, contained model rhetorical speeches and a guide to universal manners. The work was first published in Lublin in 1730 and regularly reprinted for the next thirty years. The author of pedagogical treatises and an outstanding preacher, Stefan Sczaniecki (1658-1737), left behind both Latin and Polish works. ${ }^{44}$ Jan Bielski (1716-68), for his part, authored a number of Polish history and rhetorical coursebooks, along with tragedies on the Christian martyrs and

43 See "Jan Skorski, Lechus, carmen heroicum (1745) - fragment księgi I" (ed. Mikołaj Szymański) and "Jan Skorski, Lech polski (1751) - fragment pieśni I w przekładzie Benedykta Kotfickiego" (ed. Roman Krzywy), in "Umyst stateczny i w cnotach gruntowny...": Prace edytorskie dedykowane pamięci Profesora Adama Karpińskiego, ed. Radosław Grześkowiak and Roman Krzywy (Warsaw: Wydział Polonistyki Uniwersytetu Warszawskiego, 2012), 263-91.

44 See Jerzy Kochanowicz, Podręcznik pedagogiki Stefana Sczanieckiego SJ z 1715 roku "Professio circa puerorum in virtute, sapientia et politie institutionem" (Cracow: Wydawnictwo WAM - Wyższa Szkoła Filozoficzno-Pedagogiczna “Ignatianum," 2001); Stefan Sczaniecki, Fragmenta philosophiae universae ex praelectionibus (Lublin: Typ. Collegii Lubl. Soc. Jesu, 1710); Stefan Sczaniecki, Szczera prawda przeciw obtudnemu fatszowi (Poznań: W Drukarni 
panegyrics. The printing house of a Jesuit college in Poznań published his funeral speech (in Latin and Polish) on the death of King Stanisław Leszczyński (r.1704-9 and 1733-36). Jan Antoni Poszakowski (1684-1759) was a historian, religious polemicist and author of almanacs in Latin and Polish.

From the seventeenth century onwards, the new focus on the social issues evinced by the Jesuits of the Commonwealth is evident in the works describing noble coats of arms. These writers were interested not only in the history and description of specific coats of arms, but also in deciphering the heraldic concepts and all manner of rhetorical discourses incorporating heraldic elements. The Jesuits also left numerous handwritten armorials, one of which was composed by Jan Kołozwarski $\left(c .1610-5^{2}\right)$ in 1647 . The works of Wojciech Wijuk Kojałowicz (1609-77), the rector of the Academy of Vilnius, include Herbarz rycerstwa Wielkiego Księstwa Litewskiego (The armorial of the Grand Duchy of Lithuania). Another Jesuit author of handwritten armorials was Teofil Rutka (1622-1700), who composed Orator Polonus (The Polish orator). This work was often copied and transcribed by noble readers. More importantly, Rutka was also a prolific religious writer and the author of Gladius contra Turkas (A sword against the Turks) issued in 1679, in which he encouraged Christian rulers to establish an anti-Turkish society.

The Jesuit Gabriel Rzączyński (1664-1737), widely known as the author of physiographic works, published the armorial Gemmae antiquorum [...] Polonorum (Gems of the ancient Poles) in 1700 in Poznan. This work was consistently re-edited and reprinted under modified titles between 1702 and 1715. It is a sort of guide to composing panegyrics and laudatory speeches, including descriptions of the coats of arms of the Polish nobility, annotated with classical quotations. Given that heraldic works were part and parcel of occasional writing, because they were connected with occurrences in public and private affairs, all the aforementioned armorials soon found wide appeal. Such elements were to be found, for example, in the sermons by the above-mentioned preachers Bembus and Sczaniecki. ${ }^{45}$ The monumental armorial by Kasper Niesiecki (1682-1744). Korona polska (The Polish crown), published in Lviv between 1728 and 1743 and later reprinted, proved to be the capstone of Jesuit heraldic writing. This work was the most voluminous armorial, containing historical references to noble houses and outstanding compatriots. Niesiecki's Korona polska

Kolleg. Soc. Jesu, 1719), Latin version: Nuda Veritas de Terra puri Verbi Dei pridem exorta (Poznań: Typis Clari Collegii Societatis Jesu, 1723). iej fundacji Uniwersytetu z 1611 roku, ed. Dorota Żółądź-Strzelczyk and Rafał Witkowski (Poznań: Wydawnictwo Naukowe UAM, 2011), 237-54. 
is a unique biographical source cataloguing the lives of notable Poles. As such, in terms of the level of scholarly discourse, this work could be reckoned in the same league as the genealogical literature flourishing at the time elsewhere in Europe. ${ }^{46}$

Another genre that was central to the literary tradition of early modern Jesuits was emblematic writing. Originally published in 1624 in Antwerp, the emblem book Pia desideria (Pious desires) by the Belgian Jesuit Herman Hugo (1588-1629), dedicated to the divine love (amor divinus), inspired many a writer of emblemata sacra. Similar emblem books annotated with a motto or other religious passage begun to be published in Jesuit colleges in the Polish Lithuanian Commonwealth. Hugo's opus was used for decorative purposes in churches in Poland and Lithuania. Admittedly, the emblem works of Polish and Lithuanian Jesuits have been preserved mainly in manuscripts. The emblem books by the Lithuanian Jesuit Mikołaj Mieleszko (1607-67), recently published in a critical edition, are among the most artistically accomplished. ${ }^{47}$ Mieleszko used elements of Hugo's work for his own emblem book written in 1657 , consisting of forty-seven emblems dedicated to Princess Katarzyna Zasławska-Ostrogska (1634-94), Jan III Sobieski's sister.

The Vilnius Academy press issued emblem works by Andrzej Młodzianowski (1627-86). His Auguria spei publicae (Auguries for the common hope) was dedicated to the voivode of Polotsk, Kazimierz Jan Sapieha (c.1642-1720). Every emblem consists of a copperplate engraving with an inscribed lemma, epigram, and elogium. The author relates a number of prophecies from the voivode's coat of arms, his name, his ancestors' virtues, his own personality, the circumstances of war, as well as from the fact of his having taken office so late. The final prophecy is adorned with a plate showing flowers and trees, and the lemma: Sero nata diu durant (The late ones last longer). Additionally, Młodzianowski wrote a book of forty emblem poems devoted to the life and martyrdom of the archbishop of Polotsk, St. Jozefat Kuncewicz (c.1580-1623): Icones symbolicae vitae et mortis B. Josaphat martyris (Symbolic depiction of the fife and death of Blessed Jozefat the martyr), published in Vilnius in 1675 , as well as other Latin emblem books. ${ }^{48}$ The compositions in the Icones are structured like the emblems from Auguria. The plates with inscriptions are prefaced

46 See Iwona Monika Dacka, Korona Polska Kaspra Niesieckiego: Pomnik staropolskiego piśmiennictwa heraldycznego (Warsaw: Wydawnictwo DiG, 2004), 233.

47 Mikołaj Mieleszko, Emblematy, ed. Radosław Grześkowiak and Jakub Niedźwiedź (Warsaw: Wydawnictwo Neriton), 2010.

48 Peter Maurice Daly and G. Richard Dimler, eds., The Corpus Librorum Emblematum: The Jesuit Series: Part four $(L-P)$ (Toronto: University of Toronto Press, 2005), 152-55; Paulina 
by the headings referring to the life and character of the archbishop. Under the picture there is an epigram, followed by an elogy and commentary. We should also mention here the Jesuit Karol Piotr Sawicki (1661-1733), the author of several works giving emblematic interpretations of coats of arms.

Among the distinguished Jesuit authors active in the second half of the eighteenth century, the most noteworthy are Franciszek Bohomolec (172084), Adam Naruszewicz (1733-96), and the poet Franciszek Dionizy Kniaźnin (1750-1807). Bohomolec was an eminent writer of comedies in Polish, a poet, and an essayist, as well as the author of Rozmowy o jezyku polskim (Debates on the Polish language [Warsaw, 1758). The historian, poet, and publisher Adam Naruszewicz created the first critical synthesis of the nation's history, Historia narodu polskiego (A history of the Polish nation [Warsaw, 1780-86]). The legacy of the celebrated poet and translator Franciszek Dionizy Kniaźnin includes Polish fairy tales, poems, and plays, as well as Latin poems-elegies, laments and odes. ${ }^{49}$ Other Jesuits who made their name in literature of the turn of the century included the historian, translator and essayist Jan Albertandi (17311808) and the poet, translator, and teacher Józef Koblański (1738-98). Ignacy Nagurczewski $\left(1725^{-1811)}\right.$ was a translator of classical authors such as Cicero, Demosthenes, Homer, and Virgil.

Whether in print or manuscript, the numerous works we have surveyed testify to the considerable contribution that the Jesuits- the national intellectual elite-made to Polish literature and culture in the seventeenth and eighteenth centuries. Their legacy can be defined in terms of a literature of purpose. It goes without saying that not only eminent and gifted men of letters, but also many a barely tolerable orator or poet composed sermons and poems. However, taken in its entirety, the Polish Jesuit legacy is still worth studying as a valuable historical source of information on the culture of its day. Moreover, Jesuit involvement in the social and political issues of the country in which they worked, and to which their works so frequently bear witness, was a distinctive feature of the legacy of the Jesuits of the Polish-Lithuanian Commonwealth.

Buchwald-Pelcowa, Emblematy w drukach polskich i Polski dotyczacych XVI-XVIII wieku: Bibliografia (Wrocław: Ossolineum - Wydawnictwo PAN, 1981), 122. 